\title{
Are the "nations" present in Matthew?
}

\author{
Glenna S Jackson \\ Otterbein College, Westerville, Ohio \\ Visiting Professor: University of Pretoria
}

\begin{abstract}
Traditionally, Matthew 28:16-20 has been placed in the context of a mandate to Christianize the world. This study attempts to ascertain if the gentile women in the geneology and the Canaanite woman near the center of Matthew's gospel constitute a precedent and a model for the mandate to bring the enemy tubes into the fold of Israel.
\end{abstract}

\section{INTRODUCTION}

The Old Testament nations are present in the Gospel of Matthew to the extent that four designated-enemy women are included in the genealogy and the story of the Canaanite woman is posited about midway through the gospel (15:21-28). Building on my earlier thesis that Matthew appropriates Mark's story of the Syrophoenician woman (7:24-30) for the purpose of conveying to a first-century Jewish community how one becomes a member, this is a beginning search for her and the other enemy women in the remainder of the gospel. For example, is it possible that the so-called Great Commission is really a proselytic call to bring back all the people of the biblical world under the rubric of Matthew's definition of Judaism? (While this is a total experiment and I'm eager to get feedback, I also recognize our schizophrenicia as scholars in the faith.. In the case of the story of the Canaanite woman, we want the historical Jesus to accept gentiles [after all, that's what most of us are], but we do not want him calling a woman a dog [or a bitch]. We want the world included in the Great Commission, but we are not sure how to explain the exclusivity logion found earlier in 10:5-6. These kinds of questions get to the heart not only of the historical Jesus and the Christ of faith, but also the historical Matthew and the idealized Matthew. And what about the community? Was it Jewish-Christian,

\footnotetext{
1 Prof Glenna S Jackson visited the University of Pretoria as research fellow of Prof Dr Andries $G$ van Aarde, July-October 2000. This paper was delivered at the International Society of Biblical Literature 2000 World Congress on Religion Cape Town, South Africa July 25, 2000. It was also presented at the Faculty of Theology, University of Pretoria, August 2000.
} 
Christian-Jewish, gentile-Christian, mixed, or a sectarian Jewish community in competition with formative Judaism? And, of course, these issues also address pre- and postWorld War II New Testament theology.)

For the purposes of this paper, I will include a brief history of research on 28:1620 and then spend the bulk of my time on the question of "the nations" in vs 19. I will address that question through Matthew's genealogy and story of the Canaanite woman and suggest at this point that the genealogy provides a precedent from biblical history, the story of the Canaanite woman provides the model for conversion into Judaism, and the Great Commission provides the mandate (thus, a complete circle with biblical [OT] history as well as a specific demonstration of "loving one's enemies" [Matt 5:44]).

\section{HISTORY OF RESEARCH}

Robert H Gundry notes the special Matthean vocabulary in 28:16-20, as well as the evangelist's previous inclusion of gentiles, for example the genealogy of Jesus and the descendants of Abraham through whom all the nations of the earth will be blessed. ${ }^{2}$ AmyJill Levine ${ }^{3}$ and then W D Davies and Dale C Allison ${ }^{4}$ rehearse the research done on this text and include Jeremias' conclusions that Matthew 28:16-20 is an ancient Near Eastern enthronement ritual in which Jesus receives authority, lordship and universal recognition. Others, such as Lohmeyer, Trilling, Malina and Frankemolle, Baltzer, Hubbard, and Reedy find different themes or variations of the same theme and point to Old Testament commissioning narratives. Davies and Allison then cite Kingsbury, Lange. Strecker, and Schaberg, as well as some of the above, for the arguments surrounding Matthew's originality or lack thereof." As Levine points out, "the Matthean Great Commission fails to conform perfectly to any established literary pattern, and the differences ultimately

${ }^{2}$ Gundry, Matthew: A Commentary on His Literary and Theological Art (Grand Rapids, MI: Eerdmans, 1982), 595.

${ }^{3}$ Amy-Jill Levine, The Social and Ethnic Dimensions of Matthean Salvation History (SBEC 14; Lewiston: Mellen, 1988), 176.

4 Davies and Allison, Jr., A Critical and Exegetical Commentary on The Gospel According to Saint Matthew (ICC; 3 vols.; Edinburgh: T\&T Clark, 1991-97).

' Davies and Allison, Matthew, 3.676-79. 
outweigh the similarities." 6 However, for different reasons than any of the above, she concludes that the more appropriate translation is "gentiles":

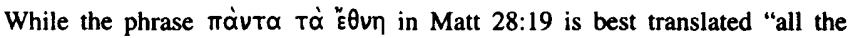
gentiles," the verse does not imply that the mission to the Jews enjoined in the second discourse has ended. Rather, the mission to the Jews must continue, since the deity has not rejected the Jews, and since the corporate community of Israel has not rejected either its tradition or its God. ${ }^{7}$
\end{abstract}

The traditional elements of interpretation in Matt 28:16-20 include, in an historicizing manner, the self-revelation of Jesus' power and authority, the mission-charge to the disciples, and the promise to be present and to help. ${ }^{8}$ Looking at the text as a Matthean invention (which includes the majority of modern scholars) ${ }^{9}$ and, therefore, a summary of the message to that gospel community, the overall themes of the similarity between but supremacy over Moses, the authority of the risen Lord, discipleship ${ }^{10}$ and evangelism, baptism, universalism (i e, an overturning of the exclusive mission statement in 10:5-6 and 15:24), eternal presence of the risen Lord, and trinitarianism, to name a few, come to light. Many scholars focus on discipleship. Michael J Wilkins, for example, understands the Great Commission in the context of "progressively advancing the group of disciples as the final focus"."

'Levine, Matthean Social History, 177.

${ }^{7}$ Levine, Matthean Social History, 278.

8 For example, see Daniel J. Harrington, The Gospel of Matthew (Sacra Pagina, 1; Collegeville, MN: Liturgical Press, 1991), 415.

9 See for example, Robert W Funk, Roy W Hoover, and The Jesus Seminar, The Five Gospels: The Search for the Authentic Words of Jesus (New York: Macmillan, 1993), 270 and Funk and The Jesus Seminar, The Acts of Jesus: The Search for the Authentic Deeds of Jesus (HarperSanFrancisco, 1998), 484-85.

10 David C Sim (The Gospel of Matthew and Christian Judaism: The History and Social Setting of the Matthean Community [Edinburgh: T\&T Clark, 1998, 196) understands this text to represent both the historical disciples and the members of the Matthean community.

$"$ Wilkins, Discipleship in the Ancient World and Matthew's Gospel (2d edn; Grand Rapids, MI: Baker, 1995) 208. 
I am most intrigued by Peder Borgen's recent work on "Proselytes, Conquest, and Mission", and, in my mind, its relationship to the Great Commission. He reflects on Philo's vision of a time when all nations will become Jewish proselytes by abandoning their own laws and accepting the Laws of Moses (Mos 2:43-44). ${ }^{12}$ Borgen then argues that

\begin{abstract}
Christian mission in the New Testament is rooted in Jewish ideas and methods of proselytism, but they are recast on the basis of the motif of eschatology and conquest. As background for missionary ideas and practices, Philo's ideas about proselytes offer a strikingly adequate background with the threefold understanding of conversion. ${ }^{13}$
\end{abstract}

That threefold understanding of conversion consists, according to Borgen, of 1) a change from many gods to the one God; 2) the ethical conversion from pagan immorality to Jewish/Christian morality; and 3) the social conversion from other peoples to one people. $^{14} \mathrm{He}$ further cites three points of agreement between Christian mission and Jewish conquest: 1) the active and conscious reaching out to the nations, for example, Matthew, the Great Commission; Paul in Gal 1:16 - "[God] was pleased to reveal [the] Son in me, in order that I might preach him among the nations; Numbers 24:7-8 - "He shall rule over many nations $\ldots$ he shall consume the nations; Targums - [see Vermes:159ff]; Philo, in Mos. 1:290-91 - "He shall rule over many nations, and his kingdom spreading every day ... [the people] shall eat up many nations; Josephus, in Ant. $4: 7 / / 10: 208-10 ; 2)$ the basis for this mission to the nations is a Jewish sovereign who has a universal claim on the nations; and 3) the Christian conquest takes place by using ideas and methods from the peaceful form of Jewish proselytism. ${ }^{15}$ Most argue that the mission

\footnotetext{
${ }_{12}$ Borgen, "Proselytes, Conquest, and Mission" in Borgen, Vernon K Robbins, and David B Gowler (eds), Recruitment, Conquest and Conflict (Emory Studies in Early Christianity; Atlanta: Scholars Press, 1998), 65.

13 Borgen, “Proselytes," 69.

14 Borgen, "Proselytes," 69-70.

15 Borgen, "Proselytes", 72-73
} 
to all the nations is of paramount importance; ${ }^{16}$ a severe interpretation of that mission is represented by Josiah G Bishop in 1914:

The Scriptures teach most emphatically that "All have sinned and come short of the glory of God" (the inner consciousness of humanity answers to this truth); that God in the gift of his [sic] Son has provided salvation for all who will accept it on the conditions of faith and obedience; that it is the duty of the church, to the extent of ability and opportunity, of every member of the church, either to "go" or "send" the message of the gospel, until "every creature" of every nation, has had a chance to hear, believe, and be saved. "The supreme business of the whole church is to give the whole gospel to the whole world." There is no option in this matter! The obligation is imperative! $!^{17}$

While I don't like imposing 21 st century sensitivities onto $19^{\text {th }}$ and early 20th century Protestant missionary movements, I am a part of that tradition and am embarrassed by this attitude and even moreso by the violence we create in all parts of the world as a religious tradition in the name of God and Jesus. Since I am spending this coming fall sabbatical at Africa University in Mutare, Zimbabwe, I am especially tuned in to anything that smacks of religious and/or Western arrogance. Beyond that, $I$ have always been intrigued by the so-called Great Commission and am finally compelled to study it because of the direction the story of the Canaanite woman has taken me.

In short, the story of the Canaanite woman in 15:21-28 and the exemplary faith exhibited by a person of such marginal status has often been set up, in an historicizing way, as the point at which Jesus woke up to the fact that he was being rejected by some of the Jewish religious leaders and his immediate group of twelve disciples didn't know what was going on; he had no choice, therefore, but to open up his mind to the possibility of including the gentiles in his mission. Hence his retort to the Canaanite woman that he

\footnotetext{
${ }^{16}$ For example, Gundry, Matthew, 593

17 Bishop, The Christians and the Great Commission: A Brief History of the Home and Foreign Missionary Work of the Christian Church, with Biographical Sketches of Foreign Missionaries (Dayton: The Christian Publishing Association, 1914), 14.
} 
was there only for the lost sheep of the house of Israel (15:24) was no longer true. ${ }^{18} \mathrm{~A}$ theological interpretation is one of pre- and post-Easter Jesus: the earthly Jesus excludes anyone but Jews; the "Risen Christ ... imposes no such limitation of sphere upon the labours of His disciples. ${ }^{19}$

Thus, many see the connection (or, more appropriately, disconnect) between the story of the Canaanite woman in 15:21-28 and the Great Commission in 28:16-20, and some add the genealogy to the mix. I would like to explore those relationships further.

\section{THE USE OF" $"$ OUOS IN MATTHEW}

The use of " $\varepsilon$ Ovos in Matthew must first be considered. As I have argued elsewhere, ${ }^{20}$ the term is used in four categories by Matthew: 1) as examples of negative ethical behavior [six times; e g, "And if you salute your brethren, what more are you doing than others? Do not even the "Evos do the same?" (5:47)] $\left.{ }^{21} 2\right)$ as outsiders to the Jewish faith [five times; e $g$, the quote from Isaiah, "The land of Zebulun and the land of Naphtali, toward the sea, across the Jordan, Galilee of the " $\varepsilon$ vos - the people who sat in darkness have seen a great light, and for those who sat in the region and shadow of death light has dawned" (4:12-16)];22 3$)$ as exemplars of the faith that Israel should have [in this case, the term " $\mathrm{E} \theta \mathrm{vos}$ is not used; rather they are the only two officially recognized gentile hearings in the Gospel of Matthew (the centurion's servant in 8:5-13 and the daughter of the

\footnotetext{
18 The literature on this topic is expansive. Recent works include a narrative-critical studies by David B Howell, Matthew's Inclusive Story: A Study in the Narrative Rhetoric of the First Gospel (JSNTSS 42; Sheffield Academic Press, 1990) and David D Kupp, Matthew's Emmanuel: Divine presence and God's people in the First Gospel (Cambridge University Press, 1996).

19 Alfred Plummer (An Exegetical Commentary on the Gospel According to S Matthew [Grand Rapids, MI: Eerdmans, 1963], 429) is an example of this view.

20 Jackson, "Have Mercy on Me": The Canaanite Woman in Matthew 15:21-28 (Sheffield, England: The Copenhagen International Seminar Series; Sheffield Academic Press, forthcoming).

${ }^{21}$ See Mtt 5:47; 6:7; 6:31-32; 18:17b; 20:18-19; $20: 25$.

22 See Mit 4:12-16; 10:5-6; 10:16a, 18b; 24:7-8; 24:9, 14.
} 
Canaanite woman in 15:21-28)], ${ }^{23}$ and 4) as participants in the salvation of the Jews [five times; for example, 28:16-20]. ${ }^{24}$

The translations of "gentiles" and "nations" in the Great Commission are both from the Greek " $\theta v \circ \varsigma$, a term that is arbitrarily rendered either way in the NRSV and other translations. Most scholars take their cues from the two different translations as best summarized through Douglas R A Hare and Daniel J Harrington, who translate it as "all the gentiles"2s and John P Meier, who translates it "all the nations" or "all the peoples." 26

So who are the nations in Matthew - non-Jews, that is, gentiles or heathens, ${ }^{27}$ or are they non-Christians? Or, are they perhaps the traditional enemies of Israel? Obviously, most commentaries assume a first-century Christian understanding of this text.

Even the Didache reflects (or anticipates) Matthew's commission: "As this broken bread was scattered upon the hills, and was gathered together and made one, so let thy Church be gathered together into thy kingdom from the ends of the earth; for thine is the glory and the power through Christ Jesus for ever."28

Erasmus (1469-1536) paraphrased the Great Commission to read as follows: "Therefore, deliver to them [the believers] whatsoever I have commanded you, [teaching them] to obey everything. I have not commanded you to observe the ceremonies of the Mosaic law, which must now vanish away like shadows in the light of evangelical truth;

\footnotetext{
${ }^{23}$ See Mtt 8:5-13 and 15:21-28.

${ }^{24}$ See Mtt 11.21-22; 12:17-21; 21:42-44; 25:32-33; 28:19-20.

${ }^{25}$ Hare and Harrington, "“Make Disciples of All the Gentiles' (Mt 28:19)," CBQ 37 (1975), 359-69.

26 Meier, "Nations or Gentiles in Matthew 28:19?" CBQ 39 (1977), 94-102. According to Robert Goldenberg (The Nations That Know Thee Not: Ancient Jewish Attitudes toward Other Religions. [New York University Press, 1998], 105), the rabbis "homogenized all gentiles into the undifferentiated category of ummot halol - 'the nations of the world' and basically had a feeling of indifference toward them." According to Sacha Stern (Jewish Identity in Early Rabbinic Writings [Leiden: Brill, 1994], 1-50), "this homogenization turned 'the nations, into a foil for the rabbis' self-perception as Jews." [in Goldenberg, p. 105, n. 371\}
}

${ }^{27}$ See Neils Peter Lemche, The Israelites in History and Tradition (Louisville: Westminster John Knox, 1998), 11.

${ }^{28}$ Henry Bettenson (ed), Documents of the Christian Church (2d edn; New York: Oxford University Press, 1963), 64. 
nor have I prescribed the constitutions of the Pharisees; but only those things that bring true innocence and godliness, and which make you truly happy and dearly beloved of God.112".29

David O Moberg expands the traditional meaning of the term "all nations" to include not just geographical expansion, but "every nook and cranny of every society" and every discipline as well. His particular concern is that scientific research must be embraced as an element of the phrase "teaching them" from the Great Commission. According to Mark Allan Powell, the text indicates that the arrival of God's kingdom has passed the point of no return." are broad and inclusive and

denote a larger field than the lost sheep of the house of Israel to whom Jesus' disciples direct their original mission of preaching and healing (10:5-6). For Matthew, the will of God revealed through the law and through the teaching of Jesus is not a cultural phenomenon for a particular ethnic or social group but universal truth that should be taught to all human beings. ${ }^{32}$

Powell, however, restricts this inclusivity to "people from all nations who have been baptized in the name of the Father, Son, and Holy Spirit .... The audience for the church's teaching may be diverse culturally and ethnically, but it will be united by the common identity assumed through baptism and by the confessions and commitments this implies". ${ }^{33}$ For Powell, the "nations" are non-Christians. ${ }^{34}$ George T Montague argues

29 Translated from the Latin by Abraham Friesen, Erasmus, the Anabaptists, and the Great Commission (Grand Rapids, MI: Eerdmans, 1998), 44.

30 Moberg, "The Great Commission and Research," Perspectives on Science and Christian Faith 51(1) (March 1999), 8-16 (9).

${ }^{31}$ Powell, God With Us: A Pastoral Theology of Matthew's Gospel (Minneapolis: Fortress, 1995), 11.

${ }^{32}$ Powell, God With Us, 68.

${ }^{33}$ Powell, God With Us, 69.

${ }^{34}$ Powell, God With Us, 114. He further suggests that the scene in 25:31-46 is a judgment on how the nonChristians have responded to the Christian missionaries whom Jesus sends to them (114). 
for a translation of "nations," rather than "gentiles," and includes Israel as part of the "nations". ${ }^{35}$ Saldarini includes Jews not living in Israel as well as non-Jews everywhere:

For the author and his group, the nations throughout the whole world are all the peoples of the Roman Empire. If the matthean group is still predominantly Jewish, ... then these statements encourage the widening of the group's teaching mission, membership, and sense of self to include non-Jews. The nations to be won over to the teachings of Jesus certainly include non-Jews predominantly, but Jewish communities within the empire and within Israel and southern Syria may also be meant. ${ }^{36}$

Anthony Saldarini concludes his discussion of ${ }^{2} \mathrm{\varepsilon} \theta \mathrm{v} \circ \mathrm{s}$ with the understanding that Matthew "does not include a theology of gentile acceptance and Jewish rejection of Jesus, as some commentators have claimed. Matthew distinguishes, rather, those who respond faithfully to God and those who do not." ${ }^{37}$ I agree with his premise that, whether "Evos refers to gentiles or nations, they "attain positive status by coming closer to Israel and Jesus and by affirming the law." What Saldarini has not said specifically is that the term " $\varepsilon v o s$ includes and may directly point to the traditional enemies of Israel.

\section{GENEALOGY}

The unique naming of the four women in Matthew's genealogy has been explored by many. Their inclusion has generally fallen under three traditional proposals: their status

35 Montague, Companion God: A Cross-Cultural Commentary on the Gospel of Matthew (New York: Paulist Press, 1989) 328. He emphasizes the "people_of all the nations" because "the Greek makes clear by using the masculine plural autous GREEK ('baptizing then') rather than the neuter auta GREEK, which would refer back to the nations as such."

36 Saldarini, Matthew's Christian-Jewish Community (University of Chicago Press, 1994), 81.

37 Saldarini, Matthew's Christian-Jewish Community, 81. It is interesting to note the argument the rabbis themselves made over the salvation of the gentiles/nations: "Rabbi Eliezer said: "All the nations will have no share in the world to come, even as it is said, "the wicked shall go into Sheol, and all the nations that forget God" (Ps 9:17). The wicked shall go into Sheol - these are the wicked among Israel. "Rabbi Joshua said to him: "If the verse had said, "The wicked shall go into Sheol with all the nations," and had stopped there, 1 should have agreed with you, but as it goes on to say "who forget God," it means there are righteous men among the nations who have a share in the world to come' (t.Sanh. 13:2)." Some rabbis understood that only Israel will be saved; others said that the righteous gentiles would be saved as well. [Cited in Alan F Segal, "Paul and the Beginning of Christian Conversion," in Borgen, Robbins, and Gowler (eds), Recruitment, Conquest, and Conflict, 96.] 
as sinners, foreigners, and/or the unusual circumstances of their pregnancies. ${ }^{38}$ According to biblical stories, the Canaanite Tamar becomes an ancestor of King David by posing as a prostitute for Judah's pleasure (Genesis 38); Rahab is a Canaanite harlot (Josh 2:1-24; 6:22-25); the Moabite Ruth seduces Boaz; and Bathsheba (wife of the Hittite Uriah; 2 Sam 11:1-12:25) is seduced (or raped) by King David. In other words, the three female ancestors of King David, along with his wife, are mentioned specifically in Matthew's "genealogy of Jesus Christ" (1:1) and they are either Canaanite, Moabite, or Hittite - a shocking introduction to a gospel story about a Jewish messiah.

The women are sometimes included or remembered in a discussion of Matthew's view of salvation history, but not often explored as the primary focus or avenue through whom we get to the end of the gospel. ${ }^{39}$ Uirich Luz, for example, embraces the nonJewishness of the women and sees it as the main reason for their inclusion in the genealogy. He provides an insight with which I both agree and disagree:

The genealogy contains a universalistic overtone; it is indicated in a hidden way that the son of David, the Messiah of Israel, brings salvation for the Gentiles. This provides a clue for the interpretation of "son of Abraham" in 1.1, which is seemingly so taken for granted and yet so striking: it reminds us of the broad Jewish tradition which sees Abraham as the father of the proselytes. The shifting of the salvation of Israel to the Gentiles, a predominant theme in the Gospel of Matthew, is addressed in its opening text. $^{40}$

\footnotetext{
${ }^{38}$ A history of research can best be found in Raymond E Brown, The Birth of the Messiah: A Commentary on the Infancy Narratives in Matthew and Luke (New York: Doubleday, 1977). See also Jane Schaberg, The Illegitimacy of Jesus (San Francisco: Harper and Row, 1987) and Glenna S Jackson, Canaanite Woman.

39 See for example, Brown, Birth, 74; Harrington, Matthew, 33; John Nolland, "The Four [Five] Women and Other Annotations in Matthew's Genealogy," NTS 43 (1997), 527-39; and J. C. Weren, "The Five Women in Matthew's Genealogy," CBO 59 (1997), 288-305. Richard Bauckham ("Tamar's Ancestry and Rahab's Marriage: Two Problems in the Matthean Genealogy," NovT 37, [19951, 313-29), Craig L Blomberg ("The Liberation of Illegitimacy: Women and Rulers in Matthew 1-2," BTB 21 [1991], 144-50) and Jackson, Canaanite Woman, add the fact that they are proselytes.

10 Luz, Matthew 1-7: A Commentary (Minneapolis: Augsburg, 1989), 110. See also Montague, Companion God, 18; Daniel Patte, The Gospel According to Matthew: A Structural Commentary on Matthew's Faith (Philadelphia: Fortress, 1987), 18.
} 
I agree with all but the last sentence; that is, there is no shift from Israel to the Gentiles, but rather an avenue for the Gentiles through Israel. It is the enemy women who make this possible and it is in that status that I am especially interested.

\section{CANAANITE WOMAN}

Some of you have heard me argue that the story of the Canaanite woman in 15:21-28, which Matthew takes from Mark's story of the Syrophoenician woman in 7:24-30, is used as a formula for conversion in Matthew's community. The form is based on the Psalms, the book of Ruth, and a rabbinic formula for conversion based on the story of the Moabite Ruth. She is, of course, one of Israel's designated enemies just as the Canaanite woman is. A summary of my thesis is paraphrased as follows:

While the Markan evangelist may have used the story of the Syrophoenician Woman to demonstrate inclusivity as an ideal and/or how it came about in the community, the author of Matthew expanded it into a paradigm for gaining acceptance into the Jewish in-group. The story of the Canaanite Woman, therefore, is not merely a description of the rewards of faith, as it has been viewed in tradition history, but is a reinforcement of Jewish law for the purpose of attaining membership in the Matthean community.

The evangelist consciously draws on Hebrew tradition in the telling of this story by imposing the language of the "psalmist in lament" on the Canaanite woman's lips. The lament is then placed in a rabbinic form that demonstrates how one becomes a member of the Jewish community to which Jesus and his disciples belong.

[And so] Jesus acquiesces and heals the woman's daughter. For many scholars, the real miracle of the story is the woman's great faith and Jesus' recognition of his own universalism. It is at this point, however, that the emphasis on the story inaugurating Jesus' mission to the gentiles has too often been distorted. The flawed presumption has been that it is the mission to the gentiles that constitutes Matthean Christianity, rather than a continuation of the Jewish tradition that allows gentiles into the faith.

Once again, the story of the Canaanite woman imitates Ruth: But Ruth said, "Entreat me not to leave you, or to return from following you; for 
wherever you go, I will go, and wherever you lodge, I will lodge; your people shall be my people, and your God my God .... The Lord do so to me and more also if I leave you, for death only will divide between you and me." (Ruth $1: 16,17 b)$

According to the rabbis, Ruth's words follow Naomi's admonishment that if Ruth is so eager to share Israel's sufferings, she must be tireless in the fulfillment of commandments and the doing of good deeds in this world. Ruth's response is a commitment to a covenant; if she is allowed to follow Naomi, she will be faithful to Naomi's God. The same is true in reverse for the Canaanite woman: if she is faithful to Jewish law, she will be allowed to gain entry into the community.

For the Matthean evangelist, the trajectory for the original covenant begins with Abraham (1:1), continues through Ruth (1:5), culminates in the story of the Canaanite Woman, and is further dramatized in the remainder of the gospel. It is, therefore, in the story of the Canaanite Woman that the gospel writer strengthens the concept of universal covenantmaking within Judaism, now continuing through Jesus.

The form of Jesus' responses to the Canaanite woman reinforces the Jewish conversion formula regarding proselytes, thereby corroborating Matthew's portrait of Jesus as a good Jew; the anti-Jewish polemic that has been a part of the history of interpretation of this text is nonexistent. Furthermore, the evangelist's redaction of this story places proselytism into Judaism at the very center of Matthew's concerns. The story of Jesus' encounter with the Canaanite woman was not included in Matthew's gospel for the purpose of recording the evangelizing of gentiles, but for the purpose of supporting the Jewish tradition of gaining entrance into the community as a proselyte.

\section{THE NATIONS IN MATTHEW 28:19}

One of the obvious questions in this query is, who are the Old Testament nations and do they exist in Matthew's time, or, in fact, did they ever exist? According to Niels Peter Lemche, the land of the Israelites, known since antiquity as Palestine, "has in the biblical historical narrative been transformed into a mighty home of the people of God."

${ }^{41}$ Lemche, Israelites, 126. 
land flowing with milk, honey and enormous grapes [Num 13:231). The occupants of the land before the Israelites are known as the "nations"; the biblical lists vary, but include the Kenites, Kenizzites, Kadmonites, Hittites, Perizzites, Rephaim, Amorites, Canaanites, Girgashites, Jebusites, and Hivites (Gen 15:19-21//Exod 23:23-24//Deut 7:1). More prohibitions are included against certain other enemies, including the Ammonites and Moabites. Some of these people are also known from other ancient sources, but most are thought to be fictive, that is "all of them shadowy if not totally spurious entities." 2 For example, Lemche argues that the term "Canaanite" is a

\begin{abstract}
literary device created in order to make a distinction between the heroes of the narrative, the biblical Israelites, and the villains, the Canaanites. They came to symbolize the non-Israelite population living in Palestine at any moment of Israel's history, whether understood to be the history of biblical Israel or of postexilic Judaism. In this way "Canaanite" might in fact simply mean the non-Jewish population of the land of Israel, irrespective of the time and circumstances in which the term appears. ${ }^{43}$
\end{abstract}

This is one reason why Matthew's use of the term Canaanite for Mark's Syrophoenician woman has been so perplexing; most view the term as a "foreign and archaic appellation. $^{44}$

Regardless of their historicity or fictiveness, the biblical story in Exodus 23:27 declares that "all the nations" are "all your enemies" and specifically the Canaanites and the Hittites are targeted (along with the Hivites). Likewise, in 7:1 and 20:17, the seven mighty nations are to be destroyed. While I cannot claim to be even scratching the surface of this topic, it occurs to me that Matthew does come full circle: the Genealogy includes the enemy women who saved Israel and the Great Commission returns to them but this time it will be Israel who saves them.

\footnotetext{
42 Lemche, Israelites, 132.

${ }^{43}$ Lemche, Israelites, 129.

4 Dermience, Alice, "La péricope de la Cananéenne (Mt is, 21-28): Rédaction et theuologie," Ethl 58 (1982), 29.
} 


\section{CONCLUSION}

As a musician, I like Graham N Stanton's use of a favorite saying with his analysis of the Great Commission, that is, "an old theme is transposed into a new key." 45 However, I think the new key is only going from C-sharp to D-flat (maybe from D-flat to C-sharp) and, therefore, still played on the same keys: the text in 28:16-20 is not a commission to make Christians out of the world, but to bring back "all the nations" of the Hebrew Bible into the House of Israel under the messiahship of Jesus of Nazareth. [Whether it is an earthly or heavenly messiahshipis another issue!] In other words, the term " $\theta$ vos may be properly interpreted to be equal to the "enemy nations" whom Matthew's Jesus has commanded to love.

\footnotetext{
45 Stanton, "The Communities of Matthew," in Jack Dean Kingsbury (ed), Gospel Interpretation: Narrative-Critical and Social-Scientific Approaches (Harrisburg. PA: Trinity Press International, 1997), 49-62 (59).
} 